\title{
MANAGING ORGANIZATIONAL CITIZENSHIP BEHAVIOR HUMAN RESOURCES OF EDUCATION IN BASIC SCHOOL IN THE SERANG CITY
}

\author{
Ranthy Pancasasti \\ Sultan Ageng Tirtayasa University \\ ranthyipb@gmail.com
}

\begin{abstract}
The purpose of this research is to know the direct influence of transformational leadership, organizational climate, team work, and emotional intelligence toward organizational citizenship behavior of human resources at State Elementary School in Serang City. This study used survey methods, and included in quantitative research. The number of population in this study as many as 433 people, the sample amounted to 100 people, taken by random sampling technique. Method of data collection were conducted by interviews, questionnaires, and documentation studies. The result of the research shows that there are positive direct influence of transformational leadership, organizational climate, team work, and emotional intelligence toward the organizational citizenship behavior of human resources personnel at elementary school in Serang city. The emotional intelligence factor is the variable that has the greatest influence on the organizational citizenship behavior. Teamwork factor is the smallest variable of influence on organizational citizenship behavior.
\end{abstract}

Keywords: Transformational Leadership, Organizational Climate, Team Work, Emotional Intelligence, and Organizational Citizenship Behavior.

Quality education is the key to a nation's success, and it should be managed in the best possible way. In line with the above, qualified teachers as a part of the human resources of educational staff, have the role as educators who can make educational reform in a planned, directed, and sustainable becomes a must.

All organizations, especially school organizations, believe that to achieve a competitive advantage of the school is to seek for an increase in individual performance of human resources of the highest educational personnel, because basically the individual performance of human resources manpower affect the Teamwork or work group human resources education personnel, and ultimately affect the overall performance of the school. A good school performance demands organizational citizenship behavior (OCB) or the social behavior of the organization's human resources manpower resources as expected by the school. Behavior that the school demand today is not only in accordance with the role of human resource personnel in the school's educational staff (in role), but also the behavior that dare to behave outside the role of human resources in the school's educational staff (extra role) so that a source of energy human educational personnel have more attitude or behavior than other human resources manpower. This extra role behavior is also called organizational citizenship behavior.

According to Colquitt, LePine, and Wesson (2014: 2), Organizational citizenship behavior (OCB) is a willingness to perform tasks beyond its basic task or willingness to do tasks outside tasks or formal roles that have been established in the absence of formal requests and rewards from the organization. The OCB indicator according to Greenberg (2010: 119) is: (1) altruism, the attribute is more important to others, (2) conscientiousness, the nature of listening, (3) civic virtue, doing good, (4) sportsmanship, and (5) courtesy, respect.

McShane and Von Glinow (2010: 414) define transformational leadership as a leadership perspective explaining how leaders change teams or organizations by creating, communicating, and modeling a vision for an organization or work unit and inspiring subordinates to work hard to realize that vision, with the indicators being: (1) building a strategic vision, (2) communicate the vision, communicating the vision, (3) modeling the vision, and (4) building commitment to the vision. 
The definition of organizational climate according to Taguiri and Litwin in Soetopo (2012: 141 ) is an internal organizational quality quality experienced by its members, influencing its behavior, and can be described with organizational characteristics. Organizational climate indicators according to Halpin in Soetopo (2012: 142), namely: (1) Open Climate which describes a situation where members love to work, work together, and openness; (2) Autonomous Climate, ie situations where there is freedom, creative opportunities, so that members have an opportunity to satisfy their needs; (3) The Familiar Climate, namely a sense of high sense between leaders and members; (4) The Paternal Climate characterized by the leadership control of the members.

According to Greenberg and Baron (2013: 309), teamwork is a team that all members have high expertise and commitment to the goals that have been determined. Teamwork indicators by Kreitner and Kinicki (2010: 132) are: (1) clear purpose, clear vision, mission and objectives of a team task; (2) informality; climate tends to be informal, comfortable and relaxed, (3) participation (4) listening (5) civilized disagreement (6) consensus decision (7) open communication (8) clear roles and work assignments (9) shared leadership, shared leadership, (10) external relations, (11) stylistic diversity, (12) self-assessment.

Kreitner and Kinicki (2010: 144) provide understanding of emotional intelligence as the ability to manage himself and interact with others in an adult and constructive way. Both share the dimensions of emotional intelligence into four, namely self-awareness, self-management, socialawareness, and relationship management.

The theoretical model of the research variables can be seen in Figure 1. This study uses survey methods, and is included in quantitative research. The number of population in this research is 433 management human resource personnel at State Elementary School in Serang City, the sample is 100 people, taken by random sampling technique. Methods of data collection were conducted by interviews, questionnaires, and documentation studies.

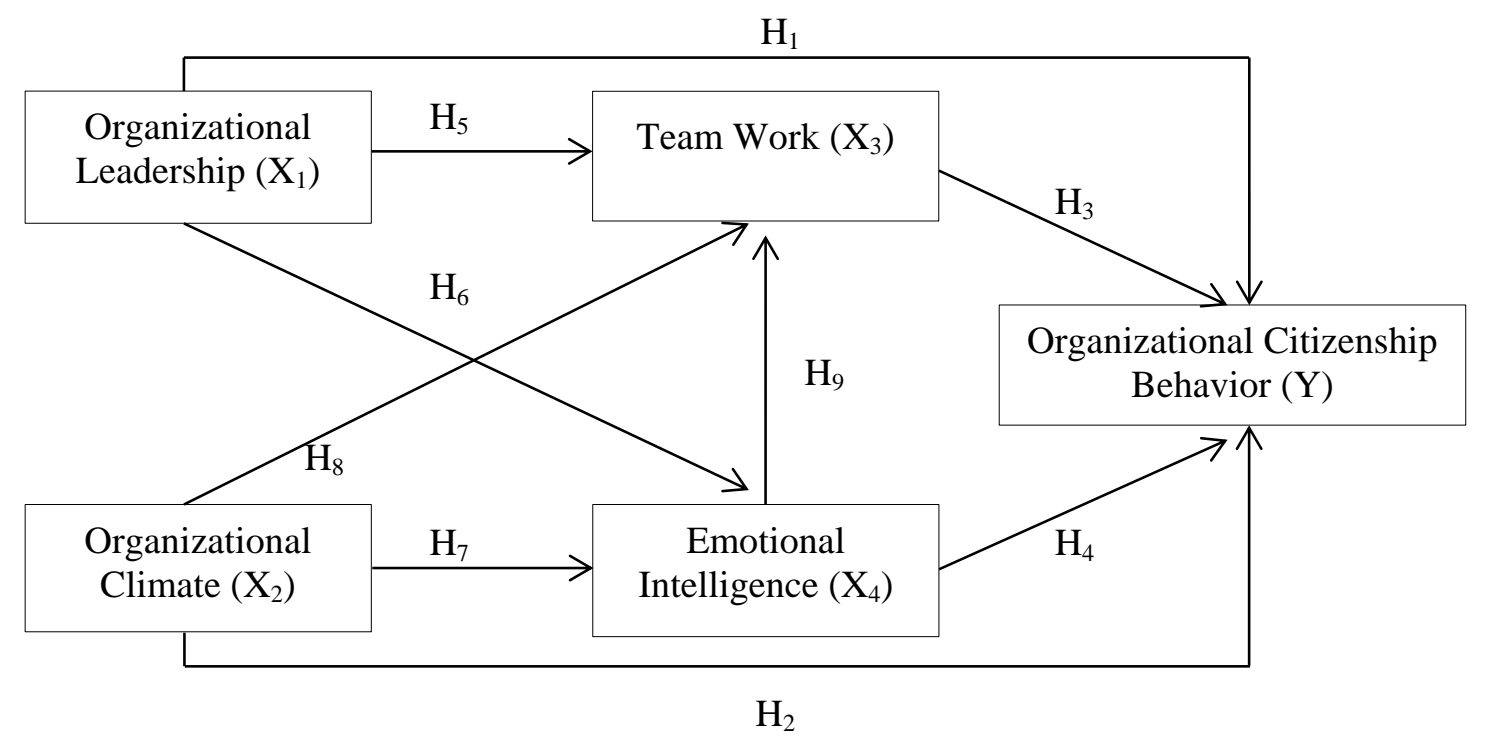

\section{RESULTS}

Recapitulation of the results of this study can be seen in Table 1. In general, the results of the study show there is a direct positive influence of transformational leadership, organizational climate, team work, and emotional intelligence to organizational citizenship behavior of human resources personnel at State Elementary School in Serang City. Figure 2 shows the full flow chart of this research variable.

Table 1. Recapitulation of Research Hypotheses Testing Results 


\begin{tabular}{|c|c|c|c|c|c|}
\hline Number & Hypothesis & $\begin{array}{l}\text { Statistic } \\
\text { test }\end{array}$ & $\begin{array}{l}\text { Path } \\
\text { coefficient }\end{array}$ & Tcount & Conclusion \\
\hline 1. & $\begin{array}{l}\text { Transformational } \\
\text { leadership }\left(\mathrm{X}_{1}\right) \text { has a direct } \\
\text { effect on Organizational } \\
\text { Citizenship Behavior }(\mathrm{Y})\end{array}$ & $\begin{array}{l}\mathrm{H}_{0}: \beta_{\mathrm{yi}} \leq 0 \\
\mathrm{H}_{1}: \beta_{\mathrm{yi}}>0\end{array}$ & $\mathrm{P}_{\mathrm{y} 1}=0.301$ & 3.354 & $\begin{array}{l}\text { H0 is rejected. } \\
\text { Meaning } \\
\mathrm{X}_{1} \text { directly } \\
\text { affect } \mathrm{Y} \text {. }\end{array}$ \\
\hline 2. & $\begin{array}{l}\text { Climate Organization }\left(\mathrm{X}_{2}\right) \\
\text { has a direct effect on } \\
\text { Organizational Citizenship } \\
\text { Behavior }(\mathrm{Y})\end{array}$ & $\begin{array}{l}\mathrm{H}_{0}: \beta_{\mathrm{y} 2} \leq 0 \\
\mathrm{H}_{1}: \beta_{\mathrm{y} 2}>0\end{array}$ & $\mathrm{P}_{\mathrm{y} 2}=0.363$ & 4.174 & $\begin{array}{l}\text { H0 is rejected. } \\
\text { Meaning } \\
\mathrm{X}_{2} \text { directly } \\
\text { affect } \mathrm{Y} \text {. }\end{array}$ \\
\hline 3. & $\begin{array}{l}\text { Teamwork }\left(\mathrm{X}_{3}\right) \text { has a direct } \\
\text { effect on Organizational } \\
\text { Citizenship Behavior }(\mathrm{Y})\end{array}$ & $\begin{array}{l}\mathrm{H}_{0}: \beta_{\mathrm{y} 3} \leq 0 \\
\mathrm{H}_{1}: \beta_{\mathrm{y} 3}>0\end{array}$ & $\mathrm{P}_{\mathrm{y} 3}=0.242$ & 2.649 & $\begin{array}{l}\mathrm{H} 0 \text { is rejected. } \\
\text { Meaning } \\
\mathrm{X}_{3} \text { directly } \\
\text { affect } \mathrm{Y} \text {. }\end{array}$ \\
\hline 4. & $\begin{array}{l}\text { Emotional Intelligence }\left(\mathrm{X}_{4}\right) \\
\text { has a direct effect on } \\
\text { Organizational Citizenship } \\
\text { Behavior }(\mathrm{Y})\end{array}$ & $\begin{array}{l}\mathrm{H}_{0}: \beta_{\mathrm{y} 4} \leq 0 \\
\mathrm{H}_{1}: \beta_{\mathrm{y} 4}>0\end{array}$ & $\mathrm{P}_{\mathrm{y} 4}=0.617$ & 6.211 & $\begin{array}{l}\text { H0 is rejected. } \\
\text { Meaning } \\
\mathrm{X}_{4} \text { directly } \\
\text { affect } \mathrm{Y} \text {. }\end{array}$ \\
\hline 5. & $\begin{array}{l}\text { Transformational } \\
\text { leadership }\left(X_{1}\right) \text { has a direct } \\
\text { effect on Teamwork }\left(X_{3}\right)\end{array}$ & $\begin{array}{l}\mathrm{H}_{0}: \beta_{31} \leq 0 \\
\mathrm{H}_{1}: \beta_{31}>0\end{array}$ & $P_{31}=0.664$ & 8.786 & $\begin{array}{l}\text { H0 is rejected. } \\
\text { Meaning } \\
\mathrm{X}_{1} \text { has direct } \\
\text { effect on } \mathrm{X}_{3}\end{array}$ \\
\hline 6. & $\begin{array}{l}\text { Transformational } \\
\text { Leadership } \quad\left(\mathrm{X}_{1}\right) \text { has an } \\
\text { immediate effect on } \\
\text { Emotional Intelligence }\left(\mathrm{X}_{4}\right)\end{array}$ & $\begin{array}{l}\mathrm{H}_{0}: \beta_{41} \leq 0 \\
\mathrm{H}_{1}: \beta_{41}>0\end{array}$ & $\mathrm{P}_{41}=0.123$ & 6.962 & $\begin{array}{l}\text { H0 is rejected. } \\
\text { Meaning } \\
\mathrm{X}_{1} \text { has direct } \\
\text { effect on } \mathrm{X}_{4}\end{array}$ \\
\hline 7. & $\begin{array}{l}\text { Climate Organization }\left(\mathrm{X}_{2}\right) \\
\text { direct effect on Emotional } \\
\text { Intelligence }\left(\mathrm{X}_{4}\right)\end{array}$ & $\begin{array}{l}\mathrm{H}_{0}: \beta_{42} \leq 0 \\
\mathrm{H}_{1}: \beta_{42}>0\end{array}$ & $P_{42}=0.639$ & 6.089 & $\begin{array}{l}\text { H0 is rejected. } \\
\text { Meaning } \\
\mathrm{X}_{2} \text { has a direct } \\
\text { effect on } \mathrm{X}_{4}\end{array}$ \\
\hline 8. & $\begin{array}{l}\text { Climate Organization }\left(\mathrm{X}_{2}\right) \\
\text { has a direct effect on } \\
\text { Teamwork }\left(\mathrm{X}_{3}\right)\end{array}$ & $\begin{array}{l}\mathrm{H}_{0}: \beta_{32} \leq 0 \\
\mathrm{H}_{1}: \beta_{32}>0\end{array}$ & $P_{32}=0.363$ & 4.051 & $\begin{array}{l}\mathrm{H} 0 \text { is rejected. } \\
\text { Meaning } \\
\mathrm{X}_{1} \text { has direct } \\
\text { effect on } \mathrm{X}_{3}\end{array}$ \\
\hline 9. & $\begin{array}{l}\text { Emotional Intelligence }\left(\mathrm{X}_{4}\right) \\
\text { has a direct effect on } \\
\text { Teamwork }\left(\mathrm{X}_{3}\right)\end{array}$ & $\begin{array}{l}\mathrm{H}_{0}: \beta_{34} \leq 0 \\
\mathrm{H}_{1}: \beta_{34}>0\end{array}$ & $P_{34}=0.640$ & 6.587 & $\begin{array}{l}\text { H0 is rejected. } \\
\text { Meaning } \\
\mathrm{X}_{4} \text { has a direct } \\
\text { effect on } \mathrm{X}_{3}\end{array}$ \\
\hline
\end{tabular}

Source: Research data, 2017.

* Significant at $\alpha=0.05$, and $\mathrm{db}=98\left(\mathrm{t}_{\text {table }}=1.984\right)$.

\begin{tabular}{|cc}
\multicolumn{1}{c}{} & \multicolumn{1}{c}{$\varepsilon_{3}=0.688$} \\
\hline \multicolumn{1}{c|}{$\mathrm{P}_{\mathrm{y} 1}=0.301$} & $\downarrow$ \\
\hline $\begin{array}{c}\text { Organizational } \\
\text { Leadership }\left(\mathrm{X}_{1}\right)\end{array}$ & Team Work $\left(\mathrm{X}_{3}\right)$ \\
\hline
\end{tabular}




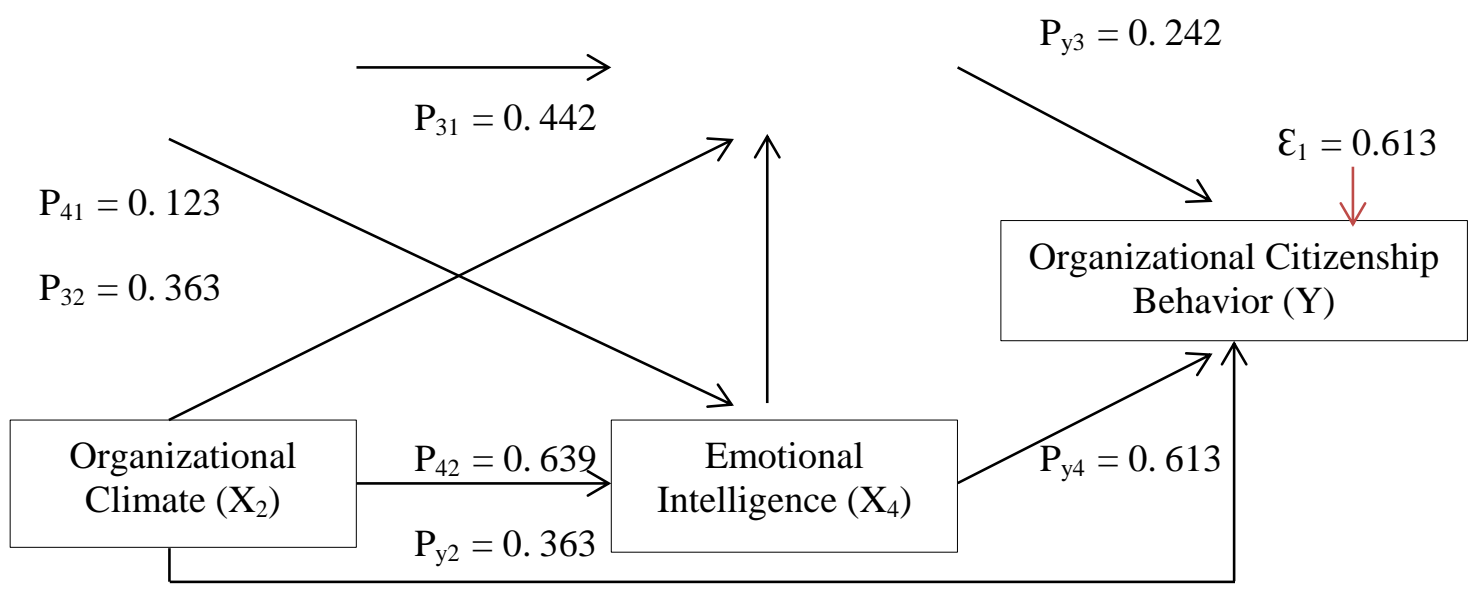

Source: Research data, 2017.

Figure 2. Complete Path Diagram of Research Variables

\section{DISCUSSION}

1. Transformational Leadership Positively Affects Organizational Citizenship Behavior

The result of hypothesis testing shows that transformational leadership has a direct positive effect on organizational citizenship behavior. This positive direct effect indicates that the Principal's transformational leadership that runs well will have a direct influence on the improvement of organizational citizenship behavior of human resource personnel at State Elementary School in Serang City. This is consistent with research from Küçükbayrak (2010), where the results show that transformational leadership, job satisfaction, organizational commitment, and organizational citizenship behavior are essential for effective organizational functions, and transformational leadership, job satisfaction, and organizational commitment have an effect on organizational citizenship behavior.

Based on the results of the study, the principal of the State Elementary School in Serang City who has a transformational leadership style is the Headmaster who: (1) has a clear, targeted and measurable vision and mission, (2) can be an example of success symbol for human resources (4) able to be an innovator and motivator for human resources of educational staff, (5) giving confidence to human resource of educational staff especially in making decision, and (6) to be objective and honest in the human resources of educational personnel, and to pay attention to the human resource needs of education personnel.

On the other hand, the human resources of education personnel at the State Elementary School in Serang City that have high organizational citizenship behavior are human resources of educational staff who are willing to: (1) perform tasks outside their main tasks and functions as human resources of education personnel ( 2 ) conducting off-the-job discussions to provide alternative solutions to the difficulties of human resources of other education personnel in the implementation of the teaching and learning process; (3) to provide suggestions for improvement in: (i) the education service human resource system at the school; and (ii) evaluating student achievement, (4) having a good attitude in the classroom and outside the classroom, and (5) caring and willing to enforce discipline in order to form good character in the students.

\section{Organizational Climate Positive Influence Against Organizational Citizenship Behavior}

The result of hypothesis testing showed that organizational climate had positive direct effect on organizational citizenship behavior. This positive direct influence indicates that conducive school organization climate will give a direct influence to the improvement of organizational citizenship behavior of human resource personnel at State Elementary School in Serang City. This is in line with the results of research from Ghanbari and Eskandari (2015), where the results show that there is a significant positive correlation between organizational climate, work motivation, and organizational citizenship behavior. 
Based on the result of research, human resources of education personnel at the State Elementary in Serang City who have high organizational citizenship behavior and work with conducive school organization climate, will feel the existence of: (1) clarity of task and role so that work completion become faster and smooth, (2) justice in the division of labor time, (3) more secure job security, and (4) decentralization of fairer decision making so as not to cause conflict in schools. This can increase job satisfaction from the human resources of the educational staff so that human resources of education personnel can better display organizational citizenship behavior.

\section{Teamwork Positive Influence Against Organizational Citizenship Behavior}

The results of hypothesis testing showed that teamwork had a positive direct effect on organizational citizenship behavior. This positive direct influence shows that solid teamwork and mutual synergy will give effect to the improvement of organizational citizenship behavior of human resource personnel at State Elementary School in Serang City. This is in accordance with the results of the study of Afolabi, et al. (2011) which explains that there is a significant influence of team leadership and teamwork on organizational citizenship behavior.

Based on the result of research, human resources of education personnel at the State Elementary in Serang City who have high organizational citizenship behavior and work in solid teamwork and synergize, will: (1) willing to share knowledge and transmit the whole model of learning that done to human resources of other education personnel, both in working hours and outside working hours, because the human resources of educational staff feel happy knowledge is useful for others, (2) willing to foster human resources other education personnel, especially mastery of ITK (Information, Technology and Communications), such as the use of computers and Information Technology tools in the field of education resulting in equal distribution of human resources, and (3) willing to assist the Principal in quality learning planning, because human resource human resources thinking they can't become a solid teamwork and synergize in planning a quality learning. It makes a solid teamwork and synergize each other can be created. This presentation shows that the teamwork of solid and synergic educational human resources in the organization of the school will establish an organizational citizenship behavior of human resources personnel which is one of the indicators of human resource performance of educational personnel to deliver the learning process to achieve the educational objectives.

\section{Emotional Intelligence Positively Affects Organizational Citizenship Behavior}

The result of hypothesis testing showed that emotional intelligence had a direct positive effect on organizational citizenship behavior. This positive direct effect indicates that good emotional intelligence from human resources of education personnel at State Elementary School in Serang City will form a high organizational citizenship behavior within the human resources of the educational staff which in turn will improve its performance. This is in accordance with the results of research from Nurwidyaningsih (2015) which shows that emotional intelligence positively affects organizational citizenship behavior.

Based on the results of research, human resources of education personnel at the State Elementary School in Serang City who have high organizational citizenship behavior and work with good emotional intelligence level will have: (1) skills in establishing effective communication to students and sources and (2) the ability to overcome the emotions that occur in their work environment, such as having patience in teaching students in the classroom, thus causing the formation of organizational citizenship behavior human resources of the educational personnel.

\section{Transformational Leadership Positively Affects Teamwork}

The result of hypothesis testing shows that transformational leadership has a positive direct effect on teamwork. This positive direct influence indicates that the transformational leadership of the 
Principal that runs well (effective) will give a direct influence on the solidity and synergy of the teamwork of human resources of the education personnel at the State Elementary School in Serang City. This is in accordance with the results of the study of Afolabi et. al., (2011) who concluded that transformational leadership positively affects teamwork.

Based on the result of the research, there are four characteristics of transformational leadership of Headmaster that can give direct influence to solidity and synergy of teamwork of human resources staff at elementary school in Serang city, such as principal that can: (1) stimulate human resources effort effort (2) having particular attention to each individual human resource personnel needs by behaving as a trainer or mentor; (3) motivating by inspiring the people around, and (4) behave as a model / role model for subordinates. Transformational leadership of such Principal is usually respected and trusted so that the solidity and synergy of teamwork of human resource staff at State Elementary School in Serang City is maintained. Based on the presentation of transformational leadership and teamwork above, there is a relationship between the two, where the Principal who has a transformational leadership style requires the support of high-performing human resource personnel workforce teamwork to achieve organizational goals.

\section{Transformational Leadership Positively Affects Emotional Intelligence}

The result of hypothesis testing shows that transformational leadership has a direct positive effect on emotional intelligence. This positive direct effect indicates that the Principal's transformational leadership that runs well (effective) will give a direct influence on the improvement of emotional intelligence of human resource personnel at State Elementary School in Serang City. This is in accordance with the results of research from Nurwidyaningsih (2015) which explains that transformational leadership positively affects emotional intelligence.

Based on the results of the study, the principal of the State Elementary School in Serang City who has a transformational leadership style is the Headmaster who: (1) has a clear, targeted and measurable vision and mission, (2) can be an example of success symbol for human resources (4) able to be an innovator and motivator for human resources of educational staff, (5) giving confidence to human resource of educational staff especially in making decision, and (6) to be objective and honest in the human resources of educational personnel, and to pay attention to the needs of human resources of education.

Based on the result of the research, there are four principal attitudes in Serang City which are tied to transformational leader, namely Principal that can be effective in: (1) create an exciting future vision, use emotional argument and show optimism and enthusiasm, (2) ) have behaviors such as sacrifices for the good of the group, become role models, and show high ethical standards, (3) provide support, encourage courage, empowerment, and provide coaching on human resources, and (4) encourage human resources questioning the status quo and finding innovative and creative solutions to organizational problems. Consistent with the presentation of transformational leadership and emotional intelligence above, there is a connection between the two, in which: (1) Principals who have a transformational leadership style require the benefits of emotional intelligence (emotional intelligence) so that they are able to run functioning well in the organization, and (2) emotional intelligence (high emotional intelligence) in a Principal who has a transformational leadership style will bring a good impact for human resource personnel as a subordinate, self Headmaster (leader) and organization itself, the main is the achievement of organizational goals.

\section{Organizational Climate Positively Affects Emotional Intelligence}

The result of hypothesis testing showed that organizational climate had positive direct effect on emotional intelligence. This positive direct influence indicates that a conducive organizational climate will give a direct impact on the improvement of emotional intelligence of human resources of education personnel at State Elementary School in Serang City. Organizational climate as a quality of the internal environment of the organization experienced by human resources personnel at the State 
Elementary School in Serang City, will affect its behavior, and can be described with the values of organizational characteristics.

Based on the results of research, human resources of education personnel at the State Elementary School in Serang City who work on a conducive organizational climate will have good emotional intelligence level, with characteristics: (1) skilled in establishing effective communication to students as well as human resources of other education personnel, and (2) have the ability to cope with the emotions that occur in their work environment, such as having patience in teaching students in the classroom. In accordance with the explanation of organizational climate and emotional intelligence above, there is a relationship between the two, where a conducive organizational climate will bring the impact of increasing emotional intelligence (emotional intelligence) from human resources of education personnel at the State Elementary School in Serang City, which in turn will improve the performance and achievement of organizational goals. Based on this, it can be concluded that the organizational climate has a positive effect on emotional intelligence.

\section{Organizational Climate Positively Affects Teamwork}

The result of hypothesis testing showed that organizational climate had positive direct effect to teamwork. This positive direct influence indicates that a conducive organizational climate will have a direct influence on the solidity and synergy of teamwork of human resource staff at State Elementary School in Serang City.

Based on the results of the research, human resources of education personnel at the State Elementary School in Serang City working on a conducive organizational climate and solid teamwork and synergizing, will: (1) be willing to share knowledge and transmit the whole learning model to the resources other human resources personnel, both in working hours and outside working hours, because human resources educational staff feel happy knowledge useful for others, (2) willing to foster human resources other education personnel, especially mastery (Information, Technology, and Communication), such as the use of computers and Information Technology tools in the field of education so that there is equal distribution of skills among human resources personnel, and (3) willing to assist the Principal in the planning of quality learning, because the human resource staff thought that they can be teamwork mutually synergize in planning a quality lesson. It makes solid teamwork can be created. Based on the exposure shows that a conducive organizational climate can form a solid and synergistic teamwork of human resources personnel in the school organization. This is one of the indicators of human resource performance of educational personnel to deliver the learning process to achieve educational goals.

\section{Emotional Intelligence Positively Affects Teamwork}

The result of hypothesis testing showed that emotional intelligence had a positive direct effect on teamwork. This positive direct effect indicates that emotional intelligence will have a direct influence on the solidity and synergy of the teamwork of human resources of education personnel at the State Elementary School in Serang City.

Based on the result of research, human resources of education personnel at elementary school in Serang city which have good emotional intelligence level, hence they have: (1) skill in establishing effective communication to students and human resources of other education personnel, and (2) ability to cope with the emotions that occur in their work environment, such as having patience in teaching students in the classroom.

In line with that, the human resources of education personnel at the State Elementary School in Serang City who have good emotional intelligence level and work in solid teamwork and synergize, then they will be willing to: (1) share knowledge and transmit the whole learning model (2) fostering the human resources of other education personnel, especially the mastery (Information, Information, etc.) on the human resources of other education personnel, whether in working hours or outside working hours, Technology and Communication), such as the use of computers and Information 
Technology tools in the field of education so that there is equal distribution of skills among human resources personnel, and (3) assisting the Principal in the planning of quality learning, because human resources that they can be teamwork who synergize in planning a quality lesson. It makes solid teamwork can be created. Based on the exposure shows that emotional intelligence human resources of good educational personnel can form a solid teamwork and synergize in school organizations. This is one of the indicators of human resource performance of educational personnel to deliver the learning process to achieve educational goals. Based on this, it can be concluded that emotional intelligence has a positive effect on teamwork.

\section{CONCLUSIONS}

The conclusions of this study are: (1) transformational leadership, organizational climate, teamwork and emotional intelligence have a direct positive effect on the organizational citizenship behavior of human resources personnel of State Elementary School in Serang City, (2) transformational leadership, organizational climate, and emotional intelligence directly affects positively to the teamwork of human resources staff at the State Elementary School in Serang City, and (3) transformational leadership and organizational climate have a direct positive effect on the emotional intelligence of human resources staff at the elementary school in Serang City. Suggestions that can be given for this research are: (1) organizational citizenship behavior human resources of education personnel at elementary school in Serang city can be improved through improvement (effectiveness) transformational leadership, organizational climate, solidity and synergy teamwork, and improvement of emotional intelligence, (2) teamwork of human resources staff at elementary school in Serang city solid and synergize can be created by increasing (effectiveness) transformational leadership, organizational climate conducive, and improvement of emotional intelligence, (3) emotional intelligence human resources education personnel at the State Elementary School in Serang City can be improved by increasing (effectiveness) transformational leadership and organizational climate conductivity.

\section{REFERENCES}

Afolabi, O. A., Adesina, A., and Aigbedion, C. (2011). Influence of Team Leadership and Team Commitment on Teamwork and Organizational Citizenship Behavior. Journal of Social Science, 21(3), 211-216.

Annekinda, S., and Rahmani, N. S. (2013). Transformational Leadership Style Relationship between the Organizational Commitment. Proceedings of Annual Paris Business and Social Science Research Conference, Crowne Plaza Hotel, Republique, Paris, France, 4 - 5 July 2013, ISBN: 978-1-922069-27-6.

Colquitt, Jason A., Jeffery A. LePine, and Michael J. Wesson. (2011). Organiatizational Behavior. New York: McGraw-Hill.

Ghanbari, S., and Eskandari, A. (2015). Organizational Climate, Job Motivation and Organizational Citizenship Behavior. International Journal of Management Perspective, Vol.1, No.3, pp. 1-14.

Greenberg, Jerald and Robert A. Baron. 2013. Behavior in Organizations. New Jersey: Pearson Education, Inc.

Hadrayani, Eka. (2015). Organizational Climate Relations, Job Satisfaction And Organizational Commitment With Civic Behavior (OCB) At Nurse At Ibnu Sina Hospital Makassar. Thesis. Makassar: Hasanuddin University.

Küçükbayrak, R. (2010). An Integrative Model of Transformational Leadership, Organizational Commitment, Job Satisfaction, and Organizational Citizenship Behavior. M.BA Thesis (Unpublished), Ankara: Middle East Technical University.

Kreitner, Robert and Angelo Kinicki. (2010). Organizational Behavior. New York: McGraw-Hill.

McShane, Steven L., and Mary Ann Von Glinow. (2010). Organizational Behavior. New York: McGraw-Hill. 
Nair, D. (2012). Impact Of Emotional Intelligence On Organizational Climate And Organizational Citizenship Behavior In Private Sector Banks. P.hD Thesis (Unpublished), Mumbai: Padmashree Dr. D. Y. Patil University.

Nurwidyaningsih, Ayu. (2015). The Influence of Transformational Leadership In Organizational Citizenship Behavior With Emotional Intelligence And Trust In Leaders As A Mediating Variable (Study At Islamic Hospital Siti Aisyah Madiun). Thesis. Surakarta: Universitas Sebelas Maret.

Nzelibe, C. G., and Yasar, M. F. (2015). The Effects of Transformational Leadership on Employees Satisfaction, Work-group Supportiveness, Commitment, and Performance: A Field Study. Nile Journal of Business and Economics, Volume 1, No. 1, Desember 2015, pp. 56-72. Accessed from http://journals.ntnu.ng/ojs/njbe/ pada tanggal 17 Juli 2016.

Rashid, M.Z.A., Sambasivan, M., Rahman, A.A. (2004). The Influence of Organizational Culture on Attitudes Toward Organizational Change. Journal of Leadership \& Organization Development, Vol. 25, No. 2, pp. 161-179. Emerald Group Publishing Limited. ISSN: 0143-7739.

Raza, S. A. (2010). Relationship Between Organizational Climate and Performance of Teachers in Public and Private Colleges of Punjab. P.hD Thesis (Unpublished), Rawalpindi: University Institute of Education and Research Pir Mehr Ali Shah Arid Agriculture University.

Robbins, Stephen P. and Timothy A. Judge. (2011). Organizational Bahavior. New Jersey: Pearson Education, Inc.

Sarinah, Lisa. (2016). The Influence of Organizational Climate, Work Motivation, and Job Stress on Quality of Employee Work Life PT. United Tractors Tbk Jakarta. Dissertation. Jakarta: Universitas Negeri Jakarta.

Setyawan, Erwin. (2010). Analysis of Factors Affecting Social Behavior of Civil Servant Organization in the Secretariat of the City of Tanjungbalai. Thesis. Medan: Universitas Sumatera Utara.

Soetopo, Hendyat . (2012). Organizational Behavior, Theory and Practice in the Field of Education. Bandung: Remaja Rosdakarya.

Titisari, Purnamie. (2014). The role of Organizational Citizenship Behavior (OCB). Jember: Mitra Wacana Media.

Wibowo. (2014). Organizational Behavior. Jakarta: Raja Grafindo Press. 